\title{
SELECTIVE SEPARATION, PRECONCENTRATION AND DETERMINATION OF Pd(II) IONS IN ENVIRONMENTAL SAMPLES BY COPRECIPITATION WITH A 1,2,4-TRIAZOLE DERIVATIVE
}

\author{
Duygu Ozdes ${ }^{1, *}$, Celal Duran ${ }^{2}$, Huseyin Serencam $^{3}$, Deniz Sahin $^{2}$, Ali Gundogdu ${ }^{4}$ and Mustafa \\ ${ }^{1}$ Gumushane Vocational School, Gumushane University, 29100, Gumushane, Turkey \\ ${ }^{2}$ Department of Chemistry, Faculty of Sciences, Karadeniz Technical University, 61080, \\ Trabzon, Turkey \\ ${ }^{3}$ Department of Food Engineering, Faculty of Engineering, Bayburt University, 69000, Bayburt, \\ Turkey \\ ${ }^{4}$ Department of Food Engineering, Faculty of Engineering, Gumushane University, 29100, \\ Gumushane, Turkey \\ ${ }^{5}$ Department of Chemistry, Faculty of Sciences, Erciyes University, 38039, Kayseri, Turkey
}

(Received December 24, 2013; revised September 30, 2014)

\begin{abstract}
A simple, sensitive, facile and low cost methodology, combined with flame atomic absorption spectrometry (FAAS), was employed to evaluate the selective separation and preconcentration of $\mathrm{Pd}(\mathrm{II})$ ions in environmental samples by using a triazole derivative as an organic coprecipitating agent without a carrier element. The developed method was systematically investigated in different set of experimental parameters that influence the quantitative recovery of $\mathrm{Pd}(\mathrm{II})$ ions. The accuracy of the method was tested by analyzing certified reference material and spike tests. The developed coprecipitation procedure has been applied to road dust, anodic slime, industrial electronic waste materials and water samples to determine their Pd(II) levels.
\end{abstract}

KEY WORDS: Palladium, Separation, Preconcentration, Carrier element free coprecipitation

\section{INTRODUCTION}

Palladium, a precious metal, is widely used in the jewelry industry and in the production of many different kinds of electronics such as semiconductors found in personal computers, cellular phones and several electronic control devices [1-3]. Due to its wide spectrum of applications, the monitoring of palladium in environmental samples is an important issue for evaluating the risks on the human health and the ecosystem that may occur in the future [4]. Concentrations of palladium in surface fresh waters and surface salt waters were found to be in the range of 0.4 to $22 \mathrm{ng} \mathrm{L}^{-1}$ and 19 to $70 \mathrm{pg} \mathrm{L}^{-1}$, respectively whereas in the dense traffic road soil samples, concentration of palladium was found to be in the range of less than 0.7 to $47 \mu \mathrm{g}$ $\mathrm{kg}^{-1}$. The World Health Organization considers that palladium exposures exhibit many possible risks to human health and environment. The human average dietary intake of palladium appears to be up to $2 \mu \mathrm{g}$ day $^{-1}$ [5]. The quantitative methods for determining of Pd(II) as well as other pollutants in industrial, environmental, geophysical, and biological samples have become an attractive research field [1-6].

Instrumental techniques, such as UV-Vis spectrometry [7], inductively coupled plasma mass spectrometry [8], X-ray fluorescence spectrometry [9], atomic emission spectrometry [10], atomic fluorescence spectrometry [11] and atomic absorption spectrometry [12] have been employed for determination of both $\mathrm{Pd}(\mathrm{II})$ and other trace metals depending on sample characteristic and employability of the equipment. Flame atomic absorption spectrometry (FAAS) is one of the most widely used technique to determine the trace and toxic elements in various environmental samples since this technique is highly selective, versatile, economical,

*Corresponding author. E-mail: duyguozdes@hotmail.com 
and faster than similar methods [13, 14]. The direct determinations of $\operatorname{Pd}(\mathrm{II})$ and also other trace elements in water samples, biological materials or geological samples is often difficult owing to their extremely low concentrations and matrix effects. Many instrumental techniques are not sensitive enough to be used for direct determination of most trace elements in complicated matrix. A preconcentration step combined with matrix separation is often required for environmental samples prior to the determination by flame atomic absorption spectrometry (FAAS) [15, 16]. The methods developed for this purpose are based on ion exchange [17], membrane filtration [18], solid phase extraction [19], fire-assay [20], cloud point extraction [21], liquid-liquid microextraction [22] and electroanalytical techniques [23].

Coprecipitation has many advantages over the above mentioned sample pretreatment methods, including rapidity, ability to obtain high preconcentration factors, relatively low costs of reagents and equipment, minimal chemical usage and possibility of separation and preconcentration of analyte ions in the same step [24-29]. In order to preconcentrate the trace metal ions in aqueous media, metal hydroxides [30] and phosphates [31] have been used as inorganic coprecipitants and acetohydrazide derivative [24] and pyrrolidinedithiocarbamate [32] have been used as organic coprecipitants with a large amount of carrier element. In the carrier element free coprecipitation (CEFC) method, only an organic ligand is used for the formation of coprecipitating agent since there is no contamination risk in this method [33-36].

This paper describes an approach to develop a sensitive, safe, rapid, simple and low cost preconcentration/matrix separation method based on CEFC for the accurate determination of $\mathrm{Pd}(\mathrm{II})$ ions level in environmental and industrial samples by FAAS. For obtaining a precipitate a triazole derivative, 4-\{[(2-hydroxyphenyl)methylene $]$ amino $\}-2-[(4-\{[(2-$ hydroxyphenyl $)$ methylene]amino -5-mercapto-4H-1,2,4-triazol-3-yl)methyl]-5-(4-methylphenyl)-2,4-

dihydro-3H-1,2,4-triazol-3-one (HAMT), was used as an organic coprecipitating agent without a carrier element. Triazole derivatives have no harmful effects on human health; on the contrary they have antibacterial, antifungal, antitubercular, analgesic, anti-inflammatory, anticancer, anticonvulsant, antiviral, insecticidal, and antidepressant properties [37]. In the present study HAMT was used for the first time as an organic coprecipitating agent for selective separation and preconcentration of $\mathrm{Pd}(\mathrm{II})$ ions. The utilization of HAMT without high amount of a carrier element prevents the excessive usage of chemical reagents and contamination risk. Before applying the method to real samples, analytical conditions for the quantitative recoveries of $\mathrm{Pd}(\mathrm{II})$ ions, including $\mathrm{pH}$ of the solution, quantity of HAMT, sample volume, standing time, centrifugation rate and time were investigated and optimized.

\section{EXPERIMENTAL}

\section{Apparatus}

Metal ion concentrations were determined by using a Perkin Elmer AAnalyst400 atomic absorption spectrometer equipped with $10 \mathrm{~cm}$ of air/acetylene-burner head, and having a deuterium background correction. Hanna $\mathrm{pH}-211$ digital (HANNA instruments/Romania) $\mathrm{pH}$ meter with glass electrode was used to measure the $\mathrm{pH}$ of the solutions. The centrifugation of the solutions was performed using Sigma 3-16P (Sigma Laborzentrifugen GmbH, Germany) centrifuge. The solid samples were digested with Milestone model Ethos D (Milestone Inc., Italy) closed vessel microwave system.

\section{Reagents and solutions}

All of the chemical reagents were purchased from Merck (Darmstadt, Germany) or Fluka (Buchs, Switzerland) and all of the solutions were prepared in distilled/deionized water. The standard and working solutions of Pd(II) ions were prepared daily by the dilution of $1000 \mathrm{mg}$ $\mathrm{L}^{-1}$ stock solutions of $\mathrm{Pd}\left(\mathrm{NO}_{3}\right)_{2}$ purchased from Sigma and Aldrich. 
HAMT (Figure 1), which was used in an analytical application for the first time in this study, was synthesized according to literature procedure [38]. A $0.5 \%(\mathrm{w} / \mathrm{v})$ HAMT solution was prepared by dissolving in dimethylsulfoxide and ethanol (1:1) mixture. The certified reference material, sandy soil standard (CRM-SA-C Sandy Soil C), were procured from HighPurity Standard Inc. (Charleston, SC).

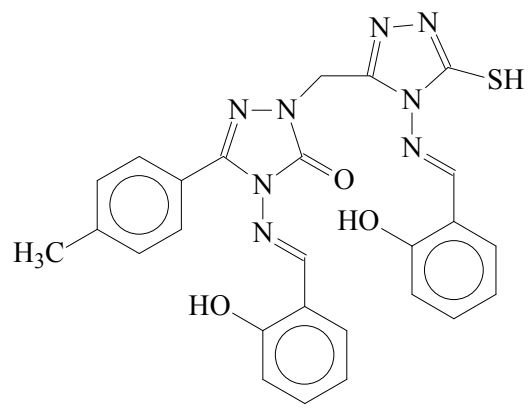

Figure 1. Chemical structure of HAMT.

\section{Model studies for coprecipitation}

A $50.0 \mathrm{~mL}$ aliquot of $0.5 \mathrm{~mol} \mathrm{~L}^{-1} \mathrm{HNO}_{3}$ solution containing $4.0 \mu \mathrm{g}$ of $\mathrm{Pd}$ (II) ions was placed in a centrifuge tube. Then $7.5 \mathrm{mg}$ of coprecipitating agent $(1.5 \mathrm{~mL} 0.5 \%(\mathrm{w} / \mathrm{v}))$ was added and the mixture was allowed to stand for $10 \mathrm{~min}$. The solution was centrifuged at $3000 \mathrm{rpm}$ during 10 $\min$ to remove supernatant. For dissolution of the precipitate, different volumes $(0.25,0.5$ and $1.0 \mathrm{~mL}$ ) of $\mathrm{HNO}_{3}$ solution was tested. The best recovery results were obtained when used 1.0 $\mathrm{mL}$ of conc. $\mathrm{HNO}_{3}$. Therefore the precipitate remained adhering to the tube was dissolved with $1.0 \mathrm{~mL}$ of conc. $\mathrm{HNO}_{3}$. Final volume was completed to $2.0 \mathrm{~mL}$ with distilled/deionized water, and then the levels of Pd(II) ions in the final solution were determined by FAAS.

\section{Analysis of real samples}

The sea water (Black sea, Trabzon/Turkey) and stream water (Şana Stream, Trabzon/Turkey) samples were filtered through a cellulose nitrate membrane filter of $0.45 \mu \mathrm{m}$ pore size and stored at $4{ }^{\circ} \mathrm{C}$ in a refrigerator in polyethylene bottles after acidified with $1 \%$ nitric acid. After sampling, high-purity $\mathrm{HNO}_{3}$ was added to the samples to keep the $\mathrm{pH}$ at approximately 0.3 . After addition of the required amount of HAMT, the proposed CEFC method was applied.

The solid samples were microwave digested prior to application of the present separation and preconcentration procedure. For that purpose, $0.750 \mathrm{~g}$ of road dust (Trabzon-Samsun motorway), anodic slime (HES/Kayseri, Turkey), $0.500 \mathrm{~g}$ of industrial electronic waste and $0.750 \mathrm{~g}$ of CRM-SA-C Sandy Soil C standard were weighed into Teflon vessels, separately. 4.5 $\mathrm{mL}$ of $\mathrm{HCl}, 1.5 \mathrm{~mL}$ of $\mathrm{HNO}_{3}, 1 \mathrm{~mL}$ of $\mathrm{HF}$ and $2 \mathrm{~mL}$ of $\mathrm{H}_{2} \mathrm{O}_{2}$ were added into the vessels. The digestion of the solid samples by microwave radiation was performed in four steps: 6 min for $250 \mathrm{~W}, 6 \mathrm{~min}$ for $400 \mathrm{~W}, 6 \mathrm{~min}$ for $650 \mathrm{~W}$, and $6 \min$ for $250 \mathrm{~W}$. During all these microwave radiations the pressure was kept at 45 bars, and the ventilation was $3 \mathrm{~min}$. At the end of the microwave digestion, the sample volume was completed to $50 \mathrm{~mL}$ with distilled/deionized water and then the method was applied. 


\section{RESULTS AND DISCUSSION}

\section{Effects of $\mathrm{pH}$ and $\mathrm{HNO}_{3}$ concentration on the recovery of Pd(II) ions}

Favorable conditions for the quantitative recoveries of $\mathrm{Pd}(\mathrm{II})$ ions are highly dependent on the $\mathrm{pH}$ of the aqueous solution. Firstly, the effects of $\mathrm{pH}$ on the recoveries of $\mathrm{Pd}(\mathrm{II})$ ions were examined in the solution $\mathrm{pH}$ range of 1.0-10.0 under optimum conditions. At $\mathrm{pH}$ values greater than 1.0 , the quantitative recoveries $(>95 \%)$ of $\mathrm{Pd}(\mathrm{II})$ ions cannot be achieved (Figure 2 (a)). Then the effects of $\mathrm{HNO}_{3}$ concentration on the recoveries of $\mathrm{Pd}(\mathrm{II})$ ions were examined in the $\mathrm{HNO}_{3}$ concentration range of $0.05-3.0 \mathrm{~mol} \mathrm{~L}^{-1}$. The precipitate formation from the HAMT ligand occurs in the $\mathrm{HNO}_{3}$ concentration range of $0.1-1.0 \mathrm{~mol} \mathrm{~L}$. At $\mathrm{HNO}_{3}$ concentrations outside of these limits and at $\mathrm{pH}$ values higher than 1.0, the precipitate starts to dissolve. Quantitative recoveries were obtained when the experiments were carried out in the $\mathrm{HNO}_{3}$ concentration range from 0.1 to $1.0 \mathrm{~mol} \mathrm{~L}^{-1}$ (Figure 2 (b)), hence all further experimental parameters were performed in $0.5 \mathrm{~mol} \mathrm{~L}^{-1} \mathrm{HNO}_{3}$ medium.

The selectivity of HAMT towards the quantitative recoveries of different metal ions ( $\mathrm{Cu}(\mathrm{II})$, $\mathrm{Pb}(\mathrm{II}), \mathrm{Cd}(\mathrm{II}), \mathrm{Mn}(\mathrm{II}), \mathrm{Co}(\mathrm{II}), \mathrm{Cr}(\mathrm{III}), \mathrm{Cr}(\mathrm{VI}), \mathrm{Fe}(\mathrm{III}), \mathrm{Ni}(\mathrm{II}), \mathrm{Zn}(\mathrm{II}), \mathrm{Al}(\mathrm{III}), \mathrm{Mo}(\mathrm{VI}), \mathrm{Pd}(\mathrm{II})$ and $\mathrm{Pt}(\mathrm{IV}))$ was checked at $0.5 \mathrm{M}$ of $\mathrm{HNO}_{3}$ concentration medium, and the quantitative recovery values were obtained for only $\mathrm{Pd}(\mathrm{II})$ ions by using the presented CEFC method. Pd(II) ions may form anionic complex like $\mathrm{Au}(\mathrm{III})$ ions in highly acidic aqueous medium. On the other hand, the surface groups of the coprecipitant used in this study are protonated in acidic medium, so strong electrostatic interactions occur between Pd(II) ions and the coprecipitant. However other metal ions are in strong cationic forms in highly acidic solution. Hence no interaction occur between these cations and the coprecipitant [39]. As a result, the recovery values for other tested metal ions were below than $10 \%$.
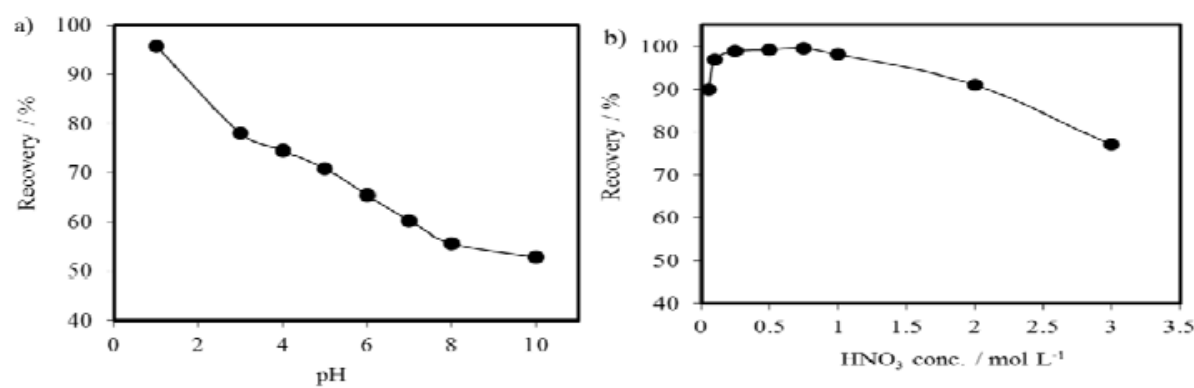

Figure 2. (a) Effect of $\mathrm{pH}$ on the recovery of $\mathrm{Pd}(\mathrm{II})$ ions and (b) Effect of $\mathrm{HNO}_{3}$ concentration on the recovery of $\mathrm{Pd}(\mathrm{II})$ ions ( $N: 3$, sample volume: $50 \mathrm{~mL}$, quantity of HAMT: 7.5 $\mathrm{mg}$, standing time: $10 \mathrm{~min}$, centrifugation rate: $3000 \mathrm{rpm}$, centrifugation time: $10 \mathrm{~min}$ ).

\section{Effect of HAMT amount}

To study the impact of the amount of HAMT on the coprecipitation of Pd(II) ions, experiments were carried out at different HAMT amounts ranging between $0-15.0 \mathrm{mg}(0-3.0 \mathrm{~mL}, 0.5 \%$ $(\mathrm{a} / \mathrm{v}))$ under optimum conditions. A graph for the recovery values of $\mathrm{Pd}(\mathrm{II})$ ions versus amount of HAMT was plotted from the obtained data (Figure 3). When the experiments were performed without HAMT, the recovery of $\mathrm{Pd}(\mathrm{II})$ ions was not quantitative $(5 \%)$. Because the precipitate, which coprecipitates the $\mathrm{Pd}$ (II) ions from the aqueous solutions, does not occur in the absence of the ligand, so it can be concluded that HAMT is necessary for the quantitative recoveries of $\mathrm{Pd}(\mathrm{II})$ ions. The recovery percentage of $\mathrm{Pd}(\mathrm{II})$ ions increased with increasing the amount of 
coprecipitating agent and by increasing the quantity of HAMT beyond the optimal amount (7.5 $\mathrm{mg}$ ), there is no significant change in the recovery efficiency, so for all further investigations 7.5 $\mathrm{mg}(1.5 \mathrm{~mL} 0.1 \%(\mathrm{w} / \mathrm{v}))$ of HAMT was used.

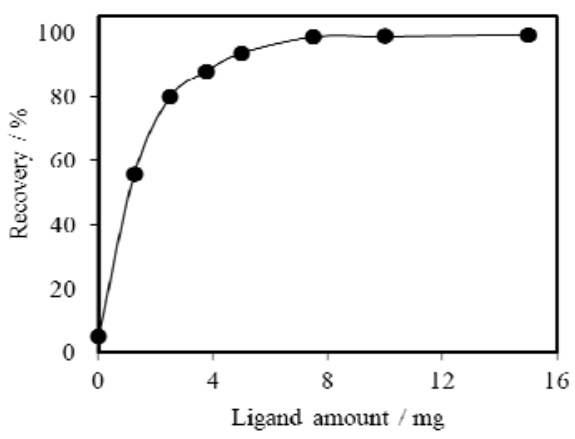

Figure 3. Effect of HAMT amount on the recovery of $\mathrm{Pd}(\mathrm{II})$ ions $\left(N: 3, \mathrm{HNO}_{3}\right.$ conc.: 0.5 mol $\mathrm{L}^{-1}$, sample volume: $50 \mathrm{~mL}$ ).

\section{Effect of sample volume}

From a general point of view, since the concentrations of $\mathrm{Pd}(\mathrm{II})$ ions in real samples are very low, an applicable separation and preconcentration procedure allows the use of a large sample volume in order to obtain high preconcentration factors. Based on this, the effect of sample volume on the quantitative recoveries of the $\mathrm{Pd}(\mathrm{II})$ ions were investigated in the sample volume range of $50-1250 \mathrm{~mL}$ under optimum conditions. For $50 \mathrm{~mL}$ sample volumes, the precipitates formed in a polyethylene tube and solutions were separated from each other by centrifugation. For sample volumes above $50 \mathrm{~mL}$, the precipitates were filtered through a $0.45 \mu \mathrm{m}$ cellulose nitrate membrane. The filter paper that contains the precipitate was dissolved by the addition of conc. $\mathrm{HNO}_{3}$ on a hot plate. Then the final volume was completed to $2.0 \mathrm{~mL}$ and the levels of $\operatorname{Pd}(\mathrm{II})$ ions in the final solution were determined by FAAS. The recovery values decreased with increasing the volume of the sample solution (Figure 4). After $750 \mathrm{~mL}$ of sample volume, the recoveries decreased considerably so the sample volume was optimized as $750 \mathrm{~mL}$ in the application of the procedure for sea and stream waters. The preconcentration factor was calculated by the ratio of the highest sample volume $(750 \mathrm{~mL})$ and the lowest final volume $(2$ $\mathrm{mL}$ ), and it was found as 375 .

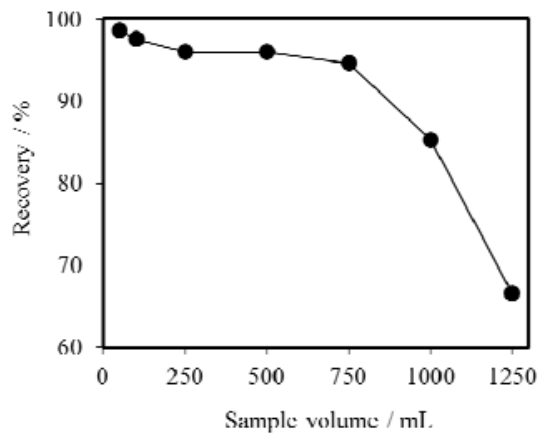

Figure 4. Effect of sample volumes on the recovery of $\mathrm{Pd}(\mathrm{II})$ ions $\left(\mathrm{N}: 3, \mathrm{HNO}_{3}\right.$ conc.: $0.5 \mathrm{~mol}$ $\left.\mathrm{L}^{-1}\right)$. 


\section{Effect of standing time, centrifugation rate and time}

The standing time and centrifugation rate and time are important parameters since they have influence on the quality of the precipitate that forms in the aqueous solution. In order to evaluate the influences of standing time, centrifugation rate and time, the performance of CEFC procedure was investigated in the standing time range of 0-120 min, centrifugation rate range of $1000-3500 \mathrm{rpm}$ and centrifugation time range of 5-30 min. It has been observed that for the formation of a quality precipitate, the standing time, centrifugation rate and time were optimized as $10 \mathrm{~min}, 3000 \mathrm{rpm}$ and $10 \mathrm{~min}$, respectively at a constant $\mathrm{pH}$ and a fixed quantity of coprecipitating agent (Table 1).

Table 1. Effect of standing time, centrifugation rate and time on the recovery of Pd(II) ions $\left(N: 3, \mathrm{HNO}_{3}\right.$ conc.: $0.5 \mathrm{~mol} \mathrm{~L}^{-1}$, sample volume: $50 \mathrm{~mL}$, quantity of HAMT: $7.5 \mathrm{mg}$ ).

\begin{tabular}{|l|c|c|}
\hline Parameter & Value & Recovery (\%) \\
\hline \multirow{5}{*}{$*$ Standing time/min } & 0 & $89.8 \pm 1.8$ \\
\cline { 2 - 3 } & 5 & $97.4 \pm 2.9$ \\
\cline { 2 - 3 } & 10 & $96.5 \pm 4.9$ \\
\cline { 2 - 3 } & 20 & $98.1 \pm 0.2$ \\
\cline { 2 - 3 } & 30 & $97.2 \pm 2.9$ \\
\cline { 2 - 3 } & 60 & $97.7 \pm 0.7$ \\
\cline { 2 - 3 } *** Centrifugation rate/rpm & 120 & $95.9 \pm 0.4$ \\
\cline { 2 - 3 } & 1000 & $89.9 \pm 2.4$ \\
\cline { 2 - 3 } & 2000 & $90.7 \pm 3.5$ \\
\cline { 2 - 3 } & 2500 & $90.8 \pm 0.4$ \\
\cline { 2 - 3 } & 3000 & $95.9 \pm 1.7$ \\
\hline \multirow{5}{*}{ Centrifugation time/min } & 3500 & $101.4 \pm 2.0$ \\
\cline { 2 - 3 } & 5 & $93.8 \pm 3.2$ \\
\cline { 2 - 3 } & 10 & $96.7 \pm 3.5$ \\
\cline { 2 - 3 } & 20 & $97.2 \pm 2.4$ \\
\cline { 2 - 3 } & 30 & $99.5 \pm 2.2$ \\
\hline
\end{tabular}

"Centrifugation rate; $3000 \mathrm{rpm}$, centrifugation time; $10 \mathrm{~min} .{ }^{* *}$ Standing time; $10 \mathrm{~min}$, centrifugation time; $10 \mathrm{~min}$.

Standing time; $10 \mathrm{~min}$, centrifugation rate; $3000 \mathrm{rpm}$.

\section{Effect of matrix ions}

The presence of alkali, alkaline earth and some transition metal ion salts in the natural water samples is an important practical factor to consider the potential of the presented CEFC procedure. Therefore, different amounts of each foreign ions, which are the major components of sea and stream water, were added to the model solutions containing $4.0 \mu \mathrm{g}$ of Pd(II) ions under the optimal conditions. As seen from Table 2, the existence of several anions and cations, and also transition metal ions did not have any significant interfering effects on the recovery of $\operatorname{Pd}(\mathrm{II})$ ions under the selected conditions. Consequently, it can be concluded that the recommended CEFC procedure can be applied to the samples that consist of various foreign ions at allowable levels.

\section{Analytical performance of the method}

The limit of detection (LOD), defined as the concentration that gives a signal equivalent to three times the standard deviation of 10 replicate measurements of the blank samples, for Pd(II) ions was found to be $0.61 \mu \mathrm{g} \mathrm{L}^{-1}$, when the sample volume was $750 \mathrm{~mL}$ and the final volume was 2.0 $\mathrm{mL}$. In order to evaluate the precision of the developed CEFC method, the procedure $(4.0 \mu \mathrm{g}$ of 
$\mathrm{Pd}(\mathrm{II})$ ions in $50 \mathrm{~mL}$ of aqueous solution) was repeated 10 times under the optimum conditions and the relative standard deviation (RSD) was found to be $3.9 \%$.

Table 2. Influences of some foreign ions on the recovery $\mathrm{Pd}(\mathrm{II})$ ions $\left(N: 3, \mathrm{HNO}_{3}\right.$ conc.: $0.5 \mathrm{~mol} \mathrm{~L}^{-1}$, sample volume: $50 \mathrm{~mL}$, quantity of HAMT: $7.5 \mathrm{mg}$, standing time: $10 \mathrm{~min}$, centrifugation rate: $3000 \mathrm{rpm}$, centrifugation time: $10 \mathrm{~min}$ ).

\begin{tabular}{|l|l|c|c|}
\hline Ions & Added as & Conc. / $\mathrm{mg} \mathrm{L}^{-1}$ & Recovery (\%) \\
\hline $\mathrm{Na}^{+}$ & $\mathrm{NaCl}$ & 10000 & $97.3 \pm 1.4$ \\
\hline $\mathrm{K}^{+}$ & $\mathrm{KCl}$ & 1000 & $94.9 \pm 1.4$ \\
\hline $\mathrm{Ca}^{2+}$ & $\mathrm{CaCl}$ & 1000 & $100.3 \pm 1.2$ \\
\hline $\mathrm{Mg}^{2+}$ & $\mathrm{Mg}\left(\mathrm{NO}_{3}\right)_{2}$ & 1000 & $96.4 \pm 0.8$ \\
\hline $\mathrm{NO}_{3}{ }^{-}$ & $\mathrm{NaNO}_{3}$ & 5000 & $93.5 \pm 4.3$ \\
\hline $\mathrm{CO}_{3}{ }^{2-}$ & $\mathrm{Na}_{2} \mathrm{CO}_{3}$ & 1000 & $94.5 \pm 0.5$ \\
\hline $\mathrm{SO}_{4}{ }^{2-}$ & $\mathrm{Na}_{2} \mathrm{SO}_{4}$ & 1000 & $93.9 \pm 2.5$ \\
\hline $\mathrm{PO}_{4}{ }^{3-}$ & $\mathrm{Na}_{3} \mathrm{PO}_{4}$ & 1000 & $92.4 \pm 0.3$ \\
\hline $\mathrm{I}^{-}$ & $\mathrm{KI}$ & 250 & $93.3 \pm 2.2$ \\
\hline $\mathrm{F}^{-}$ & $\mathrm{NaF}^{-}$ & 250 & $93.6 \pm 2.3$ \\
\hline $\mathrm{CH}{ }_{3} \mathrm{COO}^{-}$ & $\mathrm{NaCH}_{3} \mathrm{COO}$ & 250 & $93.6 \pm 1.4$ \\
\hline $\mathrm{NH}_{4}{ }^{+}$ & $\mathrm{NH}_{4} \mathrm{NO}_{3}$ & 250 & $90.3 \pm 4.5$ \\
\hline $\mathrm{Cd}(\mathrm{II}), \mathrm{Ni}(\mathrm{II}), \mathrm{Al}(\mathrm{III}), \mathrm{Pb}(\mathrm{II}), \mathrm{Cr}(\mathrm{III}), \mathrm{V}(\mathrm{V})$ & $*$ & 25 & $94.2 \pm 1.1$ \\
\hline $\mathrm{Mixed}$ & & & $91.1 \pm 1.8$ \\
\hline
\end{tabular}

*V(V) added as $\mathrm{V}_{2} \mathrm{O}_{5}$, other ions added as their nitrate salts. ${ }^{\mathrm{a}} 10760 \mathrm{mg} \mathrm{L}^{-1} \mathrm{Na}^{+}, 16110 \mathrm{mg} \mathrm{L}^{-1}, \mathrm{Cl}^{-}, 2030 \mathrm{mg} \mathrm{L}^{-1}$ $\mathrm{NO}_{3}^{-}, 250 \mathrm{mg} \mathrm{L}^{-1} \mathrm{~K}^{+}, \mathrm{Ca}^{2+}, \mathrm{Mg}^{2+}, \mathrm{CO}_{3}{ }^{2-}, \mathrm{SO}_{4}{ }^{2-}, \mathrm{PO}_{4}{ }^{3-}, \mathrm{I}^{-}, \mathrm{F}^{-}, \mathrm{CH}_{3} \mathrm{COO}^{-}, \mathrm{NH}_{4}^{+}, 10 \mathrm{mg} \mathrm{L}^{-1} \mathrm{Cd}(\mathrm{II}), \mathrm{Ni}(\mathrm{II}), \mathrm{Al}(\mathrm{III})$, $\mathrm{Pb}(\mathrm{II}), \mathrm{Cr}(\mathrm{III})$ and $\mathrm{V}(\mathrm{V})$

\section{Application to real samples}

In order to demonstrate the accuracy of the proposed separation and preconcentration method, spiked/recovery tests were applied to solid and liquid samples; road dust (Trabzon-Samsun motorway), anodic slime(HES/Kayseri, Turkey), industrial electronic waste materials, sea water (Blacksea/Trabzon, Turkey), and stream water (Şana/Trabzon, Turkey)under optimum conditions. Different amounts Pd(II) ions were spiked to digested solid samples (Table 3) and liquid samples (Table 4) and then the recommended procedure mentioned above was applied to these solutions. The results revealed good congruence between the added and measured analyte amounts. The method was also validated by analyzing a certified reference material. In CRMSA C Sandy Soil C, the Pd(II) level was $4.0 \mu^{g^{-1}}$ (given for information) and the found value was $3.9 \pm 0.2 \mu \mathrm{g} \mathrm{g}^{-1}$. A good agreement was obtained between the analytical and certified value. Finally the proposed CEFC method was applied for the analysis of Pd(II) ions in five solidliquid samples; road dust, anodic slime, industrial electronic waste materials, sea and stream water. The results obtained from the real samples are summarized in Table 5.

Table 3. Spiked recoveries of $\mathrm{Pd}(\mathrm{II})$ ions from solid samples $\left(N\right.$ : $3, \mathrm{HNO}_{3}$ conc.: $0.5 \mathrm{~mol} \mathrm{~L}^{-1}$, final volume: $2.0 \mathrm{~mL}$ ).

\begin{tabular}{|c|c|c|c|c|c|c|c|}
\hline \multirow{3}{*}{ Element } & \multirow{2}{*}{$\begin{array}{c}\text { Added } \\
(\mu \mathrm{g})\end{array}$} & \multicolumn{2}{|c|}{ Road dust } & \multicolumn{2}{c|}{ Anodic sludge } & \multicolumn{2}{c|}{$\begin{array}{c}\text { Industrial electronic waste } \\
\text { materials }\end{array}$} \\
\cline { 3 - 8 } & & Found $(\mu \mathrm{g})$ & $\begin{array}{c}\text { Recovery } \\
(\%)\end{array}$ & $\begin{array}{c}\text { Found } \\
(\mu \mathrm{g})\end{array}$ & $\begin{array}{c}\text { Recovery } \\
(\%)\end{array}$ & Found $(\mu \mathrm{g})$ & Recovery $(\%)$ \\
\hline \multirow{3}{*}{$\operatorname{Pd}(\mathrm{II})$} & 0 & $\mathrm{BDL}^{*}$ & - & $17.9 \pm 0.8$ & - & $22.4 \pm 0.5$ & - \\
\cline { 2 - 8 } & 5.0 & $4.70 \pm 0.21$ & 94.0 & $22.7 \pm 1.1$ & 96.0 & $27.0 \pm 0.9$ & 92.0 \\
\cline { 2 - 8 } & 10.0 & $9.02 \pm 0.32$ & 90.2 & $27.4 \pm 1.3$ & 95.0 & $31.9 \pm 1.4$ & 95.0 \\
\hline
\end{tabular}

* Below detection limit. 
Table 4. Spiked recoveries of $\mathrm{Pd}(\mathrm{II})$ ions from water samples $\left(\mathrm{N}: 3, \mathrm{HNO}_{3}\right.$ conc.: $0.5 \mathrm{~mol} \mathrm{~L}^{-1}$, sample volume: $50 \mathrm{~mL}$, final volume: $2.0 \mathrm{~mL}$ ).

\begin{tabular}{|c|c|c|c|c|c|}
\hline \multirow{2}{*}{ Element } & \multirow{2}{*}{ Added $(\mu \mathrm{g})$} & \multicolumn{2}{|c|}{ Sea water } & \multicolumn{2}{c|}{ Stream water } \\
\cline { 3 - 6 } & & Found( $\mu \mathrm{g})$ & Recovery $(\%)$ & Found $(\mu \mathrm{g})$ & Recovery $(\%)$ \\
\hline \multirow{3}{*}{$\operatorname{Pd}(\mathrm{II})$} & 0 & BDL & - & BDL & - \\
\cline { 2 - 6 } & 5.0 & $4.68 \pm 0.39$ & 93.6 & $4.85 \pm 0.23$ & 97.0 \\
\cline { 2 - 6 } & 10.0 & $9.65 \pm 0.78$ & 96.5 & $9.30 \pm 0.37$ & 93.0 \\
\hline
\end{tabular}

Table 5. Pd(II) ion levels in real solid/liquid samples after being applied the presented coprecipitation procedure $(N: 3$, sample volumes: $750 \mathrm{~mL}$, sample quantities: $0.750 \mathrm{~g}$ of road dust and anodic slime, $0.500 \mathrm{~g}$ of industrial electronic waste materials, final volumes: $2.0 \mathrm{~mL}$ ).

\begin{tabular}{|l|c|c|c|c|c|}
\hline \multirow{2}{*}{ Element } & \multicolumn{2}{|c|}{ Liquid samples $\left(\mu \mathrm{g} \mathrm{L}^{-1}\right)$} & \multicolumn{3}{c|}{ Solid samples $\left(\mu \mathrm{g} \mathrm{g}^{-1}\right)$} \\
\cline { 2 - 6 } & Sea water & Stream water & Road dust & Anodic slime & Industrial electronic waste materials \\
\hline $\mathrm{Pd}(\mathrm{II})$ & $4.02 \pm 0.15$ & BDL & BDL & $23.9 \pm 0.3$ & $44.9 \pm 1.8$ \\
\hline
\end{tabular}

\section{CONCLUSION}

The accurate and precise determination of Pd(II) ions in industrial and environmental solid and liquid samples based on CEFC method has been investigated. HAMT, as an organic coprecipitating agent, provides effective and selective separation and preconcentration of $\mathrm{Pd}(\mathrm{II})$ ions by collecting analyte ion on itself without using a carrier element. Contamination risk for the analyte ions from a carrier element was therefore eliminated. The proposed method has high preconcentration factor and relatively low RSD and LOD values when compared with the other methods [14, 15, 40, 41] reported in Table 6. The proposed CEFC method is also environmentally friendly since this method enables to useless chemicals. From the results obtained, it is seen that the method was successfully applied for the determination of Pd(II) ions in environmental solid and liquid samples with a low detection limit and high accuracy and precision.

Table 6. Comparison of the presented method with some recent studies based on coprecipitation reported in literature.

\begin{tabular}{|l|l|c|c|c|c|c|}
\hline Analytes & Co-precipitating agent & PF & LOD $\left(\mu \mathrm{g} \mathrm{L}^{-1}\right)$ & $\mathrm{RSD}(\%)$ & $\mathrm{pH}$ & Ref. \\
\hline $\mathrm{Pd}(\mathrm{II})$ & $\begin{array}{l}\mathrm{Cu}(\mathrm{II})-1,5- \\
\text { diphenylcarbazite }\end{array}$ & 100 & 0.40 & 6.3 & 4.5 & {$[14]$} \\
\hline $\mathrm{Pd}(\mathrm{II}), \mathrm{Au}(\mathrm{III}), \mathrm{Pb}(\mathrm{II})$ & $\begin{array}{l}\text { Ni(II)-5-methyl-4-(2- } \\
\text { thiazolylazo) }\end{array}$ & 25 & 2.10 & $<10$ & 4.0 & {$[15]$} \\
\hline $\mathrm{Pd}(\mathrm{II}), \mathrm{Au}(\mathrm{III}), \mathrm{Rh}(\mathrm{III})$ & $\mathrm{Mn}(\mathrm{OH})_{2}$ & 125 & 2.20 & 2.1 & 10 & {$[40]$} \\
\hline $\begin{array}{l}\mathrm{Pd}(\mathrm{II}), \mathrm{Au}(\mathrm{III}), \mathrm{Pb}(\mathrm{II}), \\
\mathrm{Fe}(\mathrm{III}), \mathrm{Cd}(\mathrm{II}), \mathrm{Ni}(\mathrm{II})\end{array}$ & $\mathrm{Cu}(\mathrm{II})-$ rubeanic acid & 25 & 2.50 & $1-10$ & 7.0 & {$[41]$} \\
\hline $\mathrm{Pd}(\mathrm{II})$ & HAMT & 375 & 0.61 & 3.9 & 0.3 & Present work \\
\hline
\end{tabular}

PF: Preconcentration factor; LOD: Limit of detection; RSD: Relative standard deviation.

\section{REFERENCES}

1. Imamoglu, M.; Aydin, A.O.; Dundar, M.S. Cent. Eur. J. Chem. 2005, 3, 252.

2. Shamspur, T. Bull. Chem. Soc. Ethiop. 2012, 26, 19.

3. Robles, L.C.; Aller, A.J. Talanta 1995, 42, 1731. 
Separation, preconcentration and determination of Pd(II) ions in environmental samples

4. Bujdoš, M.; Hagarová, I.; Matúš, P.; Čanecká, L.; Kubová, J. Acta Chim. Slov. 2012, 59, 124.

5. Zereini, F.; Skerstupp, B.; Alt, F.; Helmers, E.; Urban, H. Sci. Total Environ. 1997, 206, 137.

6. Boon, J.E.; Isaacs, J.A.; Gupta, S.M. J. Electron. Manuf. 2002, 11, 81.

7. Zachariadis, G.A.; Themelis, D.G.; Kosseoglou, D.J.; Stratis, J.A. Talanta 1998, 47, 161.

8. Giné, M.F.; Patreze, A.F.; Silva, E.L.; Sarkis, J.E.S.; Kakazu, M.H. J. Braz. Chem. Soc. 2008, 19, 471.

9. Zimmermann, S.; Messerschmidt, J.; Bohlen, A.V.; Sures, B. Anal. Chim. Acta 2003, 498, 93.

10. Abramovic, B.F.; Horvath, K.S.; Gaal, F.F.; Gaal, O.P. Microchem. J. 1993, 48, 137.

11. Mazej, D.; Falnoga, I.; Stibilj, V. Acta Chim. Slov. 2003, 50, 185.

12. Serencam, H.; Bulut, V.N.; Tufekci, M.; Gundogdu, A.; Duran, C.; Hamza, S.; Soylak, M. Int. J. Environ. Anal. Chem. 2013, 93, 1484.

13. Woldemariam, D.M.; Chandravanshi, B.S. Bull. Chem. Soc. Ethiop. 2011, 25, 169.

14. Ozturk, N.; Bulut, V.N.; Duran, C.; Soylak, M. Desalination 2011, 270, 130.

15. Soylak, M.; Tuzen, M. J. Hazard. Mater. 2008, 152, 656.

16. Sharma, R.K.; Pandey, A.; Gulati, S.; Adholeya, A. J. Hazard.Mater. 2012, 209, 285.

17. Gomes, C.P.; Almeida, M.F.; Loureiro, J.M. Sep. Purif. Technol. 2001, $24,35$.

18. Soylak, M.; Unsal, Y.E.; Kizil, N.; Aydin, A. Food. Chem. Toxicol. 2010, 48, 517.

19. Ghaedi, M.; Niknam, E. Bull. Chem. Soc. Ethiop. 2010, 24, 11.

20. Jackson, S.E.; Fryer, B.J.; Gosse, W.; Healey, D.C.; Longerich, H.P.; Strong, D.F. Chem. Geol. 1990, 83, 119.

21. Shokrollahi, A.; Ghaedi, M.; Gharaghani, S.; Fathi, M.R.; Soylak, M. Quim. Nova 2008, 31, 70.

22. Soylak, M.; Yilmaz, E. Desalination 2011, 275, 297.

23. Jorge, E.O.; Neto, M.M.; Rocha, M.M. Talanta 2007, 72, 1392.

24. Ozdes, D.; Duran, C.; Bektas, H.; Tufekci, M.; Soylak, M. Spectrosc. Lett. 2012, 45, 330.

25. Serencam, H.; Duran, C.; Ozdes, D.; Bektas, H. Acta Chim. Slov. 2013, 60, 287.

26. Bulut, V.N.; Ozdes, D.; Bekircan, O.; Gundogdu, A., Duran, C.; Soylak, M. Anal. Chim. Acta 2009, 632, 35.

27. Bahadır, Z.; Bulut, V.N.; Ozdes, D.; Duran, C.; Bektas, H.; Soylak, M. J. Ind. Eng. Chem. 2014, 20, 1030.

28. Ozdes, D.; Duran, C.; Serencam, H.; Bayrak, H. At. Spectrosc. 2013, 34, 164.

29. Ozdes, D.; Duran, C.; Bayrak, H.; Bulut, V.N.; Tufekci, M. Clean - Soil, Air, Water 2012 , $40,211$.

30. Ueda, J., Kagaya, S. Bull. Chem. Soc. Jpn. 1992, 65, 1496.

31. Kagaya, S., Araki, Y.; Hirai, N.; Hasegawa, K. Talanta 2005, 67, 90.

32. Atsuya, I.; Itoh, K.; Ariu, I. Pure Appl. Chem. 1991, 63, 1221.

33. Duran, C.; Bulut, V.N.; Gundogdu, A.; Ozdes, D.; Yildirim, N.; Soylak, M.; Senturk, H.B.; Elci, L. J. Hazard. Mater. 2009, 167, 294.

34. Duran, C.; Bulut, V.N.; Ozdes, D.; Gundogdu, A.; Soylak, M. J. AOAC Int. 2009, 92, 257.

35. Bulut, V.N.; Duran, C.; Gundogdu, A.; Soylak, M.; Yildirim, N.; Elci, L. Talanta 2008, 76, 469.

36. Duran, C.; Tumay, S.O.; Ozdes, D.; Serencam, H.; Bektas, H. Int. J. Food Sci. Tech. 2014, 49, 1586.

37. Şahin, D.; Bayrak, H.; Demirbaş, A.; Demirbaş, N.; Karaoğlu, Ş.A. Turk. J. Chem. 2012, $36,411$.

38. Demirbas, A.; Sahin,D.; Demirbas, N.; Karaoglu, S.A.; Bektas, H. Turk. J. Chem. 2010, 34, 347.

39. Navarro, R.; Saucedo, I.; Gonzalez, C.; Guibal, E. Chem. Eng. J. 2012, 185-186, 226. 
40. Mohammadi, S.Z.; Karimi, M.A.; Hamidian, H.; Baghelani, Y.M.; Karimzadeh, L. J. Chil. Chem. Soc. 2012, 57, 1004.

41. Soylak, M.; Erdogan, N.D. J. Hazard. Mater. 2006, 137, 1035. 